\title{
THE EFFECT OF GCG IMPLEMENTATION AND RISK PROFILE ON FINANCIAL PERFORMANCE AT GO-PUBLIC NATIONAL COMMERCIAL BANKS
}

\author{
Sri Haryati ${ }^{1}$ \& Emanuel Kristijadi ${ }^{2}$ \\ STIE Perbanas Surabaya \\ ('haryati@perbanas.ac.id; ${ }^{2}$ didik@perbanas.ac.id)
}

\begin{abstract}
The research tests the effect of the risk profile and the application of corporate governance on financial performance at go-public national commercial bank. The data were taken from their financial statement and GCG assessment published during 2008-2010, analyzed using SEM with generalized structured component analysis (GSCA). It shows that risk profile has no significant and positive effect on the financial performance. Among the four risk profiles, liquidity risk has the best discriminate validity. However, GCG has significant and positive effect on the financial performance, and only financial and non financial transparency has the best convergent validity. Bank's five financial performance indicators have good validity. Beside, ROA, NIM and CAR have good validity in which ROA has the highest loading estimate.
\end{abstract}

Keywords: good corporate governance, risk profile, profitability, capital

\section{INTRODUCTION $^{\mathbf{i}}$}

Global financial reform has made banking industries increase their compliance with international standards, improve risk management, and increase undertake early detection of the problems being faced. In addition, the increasing complexity of risks also have made them improve performance, protect the interests of stakeholders and improve compliance with existing legislation. In such a condition, they also have to increase the need for the implementation of Good Corporate Governance (GCG) (Bank Indonesia, PBI. No 84: 2006).

Bank Indonesia (BI) as the monetary authority and as the international community has established, and improved laws, ethical values and methodology. Besides that, bank industries have to do risk assessment and to have their soundness by integrating the four components namely risk profile, GCG, profitability and capital (Directorate of Banking Research and Regulation, 2011: 4). For example, banks are required to undertake self-assessment performance (soundness) by using the Risk-based Bank Rating (RBBR) with coverage of an assessment of the risk profile and corporate governance, earnings and capital (Bank Indonesia, SEBI. No. 13: 2011). Such efforts must be done by paying attention to the relationship and influence of some factors which can increase the banks' soundness.

With Good corporate governance (GCG), it is intended that the bank must implement the principles of fairness, where in implementing such principle, they should realize the application of risk management (Bank Indonesia, PBI 84: 2006). In this case, the results of GCG selfassessment must also be published by the gopublic commercial banks during three years before the implementation the bank assessment as based on RBBR. From this publication, the banks are ranked in such as their composite rankings 2 (good predicate) that is equal to 47.7 per cent composite rankings 1 (predicate very good) is 46 per cent, and the remaining rankings composite 3 (pretty good) and 5 (not good) is 6.4 per cent as presented in Table 1.

As seen on Table 1, the banks' capital (CAR) for all banks have been complied with on all predicate GCG and have exceeded the capital 
Table 1. Predicates of GCG, ROA and CAR on Go-public Commercial Banks

2008-2010

\begin{tabular}{|c|c|c|c|c|c|c|c|c|c|c|}
\hline \multirow{2}{*}{ No } & \multirow{2}{*}{ Bank } & \multicolumn{3}{|c|}{2008} & \multicolumn{3}{|c|}{2009} & \multicolumn{3}{|c|}{2010} \\
\hline & & GCG & ROA & CAR & GCG & ROA & CAR & GCG & ROA & CAR \\
\hline 1 & ArthaGraha International & G & $0.34 \%$ & $14.90 \%$ & G & $0.44 \%$ & $13.87 \%$ & G & $0.76 \%$ & $13.74 \%$ \\
\hline 2 & BumiArta & G & $2.07 \%$ & $31.15 \%$ & G & $1.71 \%$ & $28.42 \%$ & G & $1.47 \%$ & $24.64 \%$ \\
\hline 3 & Bukopin & G & $1.66 \%$ & $11.20 \%$ & $\mathrm{G}$ & $1.46 \%$ & $14.36 \%$ & $\mathrm{G}$ & $1.65 \%$ & $11.82 \%$ \\
\hline 4 & Central Asia & VG & $3.42 \%$ & $15.78 \%$ & VG & $3.40 \%$ & $15.33 \%$ & VG & $3.51 \%$ & $13.50 \%$ \\
\hline 5 & CIMB Niaga & VG & $1.10 \%$ & $15.59 \%$ & VG & $2.11 \%$ & $13.59 \%$ & VG & $2.73 \%$ & $13.24 \%$ \\
\hline 6 & Danamon & VG & $2.01 \%$ & $13.37 \%$ & VG & $1.78 \%$ & $13.25 \%$ & VG & $3.34 \%$ & $13.93 \%$ \\
\hline 7 & ICB BumiPutera & G & $0.09 \%$ & $11.78 \%$ & G & $0.18 \%$ & $11.91 \%$ & G & $0.24 \%$ & $12.63 \%$ \\
\hline 8 & Internasional Indonesia & VG & $1.25 \%$ & $19.58 \%$ & G & $-0.05 \%$ & $14.71 \%$ & VG & $1.01 \%$ & $12.65 \%$ \\
\hline 9 & Kesawan & $\mathrm{F}$ & $0.23 \%$ & $10.34 \%$ & $\mathrm{~F}$ & $0.30 \%$ & $12.47 \%$ & $\mathrm{~F}$ & $0.17 \%$ & $9.92 \%$ \\
\hline 10 & Mandiri & VG & $2.69 \%$ & $15.66 \%$ & VG & $3.13 \%$ & $15.43 \%$ & VG & $3.63 \%$ & $13.36 \%$ \\
\hline 11 & Mega & $\mathrm{G}$ & $1.98 \%$ & $16.09 \%$ & $\mathrm{G}$ & $1.77 \%$ & $18.01 \%$ & $\mathrm{G}$ & $2.45 \%$ & $15.03 \%$ \\
\hline 12 & Mutiara & Un F & $0.37 \%$ & $15.66 \%$ & $\mathrm{G}$ & $3.84 \%$ & $10.02 \%$ & $\mathrm{G}$ & $2.53 \%$ & $11.16 \%$ \\
\hline 13 & BNI & $\mathrm{G}$ & $1.12 \%$ & $13.47 \%$ & VG & $1.72 \%$ & $13.78 \%$ & VG & $2.49 \%$ & $18.63 \%$ \\
\hline 14 & OCBC NISP & VG & $1.54 \%$ & $17.01 \%$ & VG & $1.79 \%$ & $18.00 \%$ & VG & $1.09 \%$ & $17.63 \%$ \\
\hline 15 & Panin & $\mathrm{G}$ & $1.75 \%$ & $20.31 \%$ & $\mathrm{G}$ & $1.31 \%$ & $21.79 \%$ & $\mathrm{G}$ & $1.87 \%$ & $16.58 \%$ \\
\hline 16 & Permata & VG & $1.70 \%$ & $10.80 \%$ & VG & $1.39 \%$ & $12.16 \%$ & VG & $1.89 \%$ & $14.13 \%$ \\
\hline 17 & BRI & VG & $4.18 \%$ & $13.18 \%$ & VG & $3.73 \%$ & $13.20 \%$ & VG & $4.64 \%$ & $13.76 \%$ \\
\hline 18 & Swadesi (Of India) & $\mathrm{G}$ & $2.53 \%$ & $33.27 \%$ & VG & $2.93 \%$ & $32.90 \%$ & $\mathrm{G}$ & $2.93 \%$ & $26.91 \%$ \\
\hline 19 & BTPN & VG & $4.48 \%$ & $23.67 \%$ & VG & $3.42 \%$ & $18.50 \%$ & VG & $3.99 \%$ & $23.47 \%$ \\
\hline 20 & BTN & $\mathrm{G}$ & $1.90 \%$ & $16.14 \%$ & $\mathrm{G}$ & $1.47 \%$ & $21.49 \%$ & VG & $2.05 \%$ & $16.74 \%$ \\
\hline 21 & Victoria & G & $0.88 \%$ & $22.77 \%$ & G & $1.10 \%$ & $16.86 \%$ & $\mathrm{G}$ & $1.70 \%$ & $11.00 \%$ \\
\hline
\end{tabular}

Sources: Published Report, processed

requirement on a low to moderate risk profile (PBI. 14/18/PBI/2012). However, if viewed from the earnings performance (ROA), there are some banks that have GCG predicate of being Good (G) and Very Good (VG) but it is a relatively low ( 0,5 per cent - 1,25 per cent) and even less than 0.5 per cent.

With the implementation of PBI No13/1/ $\mathrm{PBI} / 2011$ to assess bank soundness beginning in 2012, the banks' soundness should be measured for example they should do self-assessment of the factors: risk profile, GCG, profitability and capital. Since the banks are recommended to do improvement based on the regulation stipulated by BI, there must be some improvements especially for the go-public commercial banks. This study aims to test the effect of the risk profile and the application of GCG on financial performance at go-public national commercial banks. By doing so, the researcher can provide the findings for further consideration when undertaking self-assessment to assess bank soundness.

\section{THEORETICAL FRAMEWORK}

The presence of the global financial crisis has prompted the need to improve the effectiveness of risk management and corporate governance. Therefore, the banks should identify their problems early, perform follow-up more quickly, and implement the risk management and corporate governance. Accordingly, the provisions of the commercial bank soundness and the assessment can be enhanced through Bank Indonesia (BI) regulation No. 13/1/PBI/2011. In this regulation, the banks' rating is conducted by using a risk-based approach called Risk-Based Bank Rating (RBBR). In connection with the application of the regulation concerning the soundness of the commercial banks, the banks are obliged to conduct a self assessment of their soundness by approaching to risk assessment with coverage that includes the factors such as risk profile, GCG, profitability (earnings) and capital to produce a composite rating of bank soundness (PBI No.13/1/PBI/2011). 
Conventional commercial banks are required to apply risk management that includes eight risks such as credit risk, market risk, liquidity risk, operational risk, legal risk, reputation risk, strategic risk and compliance risk. To determine the level of bank's each risk, it can be measured as the following: rating 1 (low), rating 2 (low to moderate), rating 3 (moderate), rating 4 (moderate to high) and rating of 5 (high); (Bank Indonesia regulation $11 / 25 / \mathrm{PBI} / 2009)$. The inherent risk is attached to the risk assessment of a bank's business activities that can either be quantifiable or unquantifiable. There are some indicators that can be quantified from eight existing risks such as credit risk, market risk, and liquidity risk.

\section{Credit Risk}

Credit risk is the risk of failure of the debtor and other parties to fulfill obligations to the bank. The indicators used to assess the inherent risk of credit risk include such as (1) The composition of the asset portfolio and the level of concentration, (2) quality of provision and adequacy of reserve funds, (3) the provision funding strategies and (4) external factors (Bank Indonesia: SEBI No.13/24/DPNP:2011). Qualitative assessment which can be measured through the publication of financial statement include: (1) assets per balance sheet accounts to total assets, (2) assets and low quality off balance sheet items to total assets and off-balance sheet, (3) non performing earning assets and non performing offbalance sheet to total assets and off-balance sheet, (4)low quality loans to total loan, (5) nonperforming loans to total loans and (6) allowance for impairment losses on loans to total loans. From six ratios, ratio non-performing loans to total loans (NPL) should be published (Bank Indonesia: SEBI 13/30/DPNP: 2011).

\section{Market Risk}

Market risk is the risk on balance sheet and off balance sheet, including derivatives transaction due to change in market conditions. Indicators of risk assessment inherent market risks are: (1) the volume and portfolio composition, (2) loss of potential interest rate risk in the banking book and (3) strategies and business policy (Bank Indonesia: SEBI No.13/24/DPNP:2011).

There are four ratios used for the indicators of assessment, namely: (1) derivative trading assets and fair value option (FVO) to total assets, (2) liabilities and obligations FVO derivatives to total Liabilities (3) Total derivatives to Total Assets and (4) total net open position (PDN) to Total Capital. The ratio shall be published is PDN to Capital ratio.

\section{Liquidity Risk}

Liquidity Risk is the risk due to the inability of the bank to meet its maturing obligations from cash flow funding, liquid assets that can be pledged without disturbing the activities and financial condition of banks. The parameters used to assess liquidity risk includes such as: (1) composition of assets, liabilities, and off-balance sheet transactions, (2) assets and liabilities concentration, (3) vulnerability to funding requirement and (4) access to funding sources (Bank Indonesia: SEBINo.13/24/DPNP:2011). The assessment of liquidity risk that can be quantified through the publication of financial statement is the ratio of Primary and Secondary Liquid Assets to Total Assets.

\section{Operational Risk}

Operational risk is the risk that occurs due to failure in internal processes, people, systems or external events. There are three methods for measuring the bank's operational risk such as basic indicator approach, standardized approach, and advanced measurement approach (Basel Committee on Banking Supervision: 2004). In the Basic Indicator Approach, banks have provide capital to cover the operational risk equal to the average percentage of gross income over the previous three years, where the gross income is a net operating income (Basel Committee on Banking Supervision: 2004: 138).

Financial ratios that measure bank operations are compared to operating income or operating expenses (ROA). This ratio is one of the bank's performances that must be published in the quarterly publication of financial statement 
(Bank Indonesia: SEBI. No.13/30/DPNP: 2011). There is tradeoff between risks and returns: namely when the bank increases the risk position of the bank returns decrease, and vice versa (Hempel and Simonson,1999: 70). Five categories of financial risks are: credit risk, liquidity risk, leverage risk and interest rate risk. Interest rate risk can be measured by the ratio of interestsensitive assets to interest-sensitive liabilities or gap between interest sensitive assets to interestsensitive liabilities (Hempel and Simonson, 1999: 93-94).

Previous studies using banks to assess the effect of the banks' risk on the banks' performance shows that credit risk has a significant negative relationship to the bank's stock return (Landschoot and Vennet, 2002). Thus, credit risk management has a vital role in predicting the bank's financial performance (Pandel, 2012) .

When referring to $\mathrm{BI}$ regulation about risk profile and some evidences as in the results of the previous studies, the first hypothesis in this study can be stated as follows:

$\mathrm{H}_{1}$ : The risk profile (credit, liquidity, market, operation) has significant and positive effect on go-public commercial banks.

The higher risk faced by banks can also increases the need for GCG practices in the bank industries. This effort is done to maintain or anticipate future risks. In other words, the higher the risk profile of the bank, the more the banks require implementing GCG. For that reason, the second hypothesis can be stated as follows.

$\mathrm{H}_{2}$ : The risk profile has a positive effect on the GCG implementation of the Go-public national commercial banks.

The next is related to the effort of how to increase the performance of the bank. In this case, BI has set the rules on the implementation of GCG such the banks should apply GCG. In addition to this, the banks must also be complied with other regulation for example they have to protect the interests of stakeholders. The previous studies that examined the effect of GCG implementation indicate that GCG has significant influence on the performance of profitabil- ity. The measurements are conducted using by ROA, ROE, ROI, and NPM (Trinanda and Didien, 2012) and; GCG significant positive effect on bank performance (Sam 'Ami: 2008), the results of research Peong and Devinaga (2010) show that corporate governance has a significant positive effect on bank performance. The results of other studies indicate that the implementation of GCG mediated by earnings management does not significantly affect the financial performance (Yustriatiet al, 2010); Cristoper (2009) found that the implementation of GCG has a significant effect on the performance of banks; IRR has a significant effect on the cumulative abnormal return to the company on the Stock Exchange, credit risk, liquidity risk and solvency risk effect was not significant (Nurhidayah and Budi, 2012). Based on the evidences above, the third hypothesis can be stated as follows:

$\mathrm{H}_{3}$ : GCG implementation has positive and significant effect on the financial performance of go-public national commercial banks.

The next is that to determine the composite rating of the banks that includes (1) coverage of risk profile assessment which is the first line of defense, (2) GCG which is a second line of defense, (3) profitability that is a third line of defense and as a last line of defense is the capital. From this, the fourth hypothesis of this study is stated as follows:

$\mathrm{H}_{4}$ : GCG is a mediating variable in the relationship between risk profile and financial performance in go-public national commercial banks.

\section{Research Method}

The subjects of this study were the go-public national commercial banks during the study period of 2008-2010. These banks are considered to have published their GCG reports on the bank's website. Based on these criteria, the subjects consisted of 19 foreign exchange national commercial banks and 2 of non foreign exchange national commercial banks. 


\section{Research Variables:}

1. The risk profile is indicated by four variables as the following the following:

a. Credit Risk: the ratio of non-performing loan (NPL)

b. Market Risk: Interest Rate Risk ratio (IRR), measurement of foreign exchange risk which is not used because of among the subjects, there is no foreign exchange bank

c. Liquidity risk: the ratio of Liquid Assets (Primary and Secondary) to Total Assets

d. Operational Risk: BOPO

To measure the risk profile of the respective ratios, the consideration is as follows: low (1), low to moderate (2), moderate (3), moderate to high (4) and high (5) using statistic tool to determine the risk profile by calculating the area \pm 2 standard deviations from the average ratio respectively monthly for 6 months.

2. Composite Rating GCG implementation using the results of the self assessment of each bank are published on the bank's website and use the 11 assessment indicators in accordance with Bank Indonesia.

3. The variables used to measure the bank's performance:

a. Earnings, consisting of:

- Return on Assets (ROA) is the ratio between the earning before tax to total assets. This is measured semi annually from June 2008 to December 2010;

- Net Interest Margin (NIM) is the ratio between Net Interest Income to Earning Assets measured semiannually from June 2008 to December 2010 and,

- Operating Profit Growth (GLOp) is the ratio between profit margin Operating period $t-1$ to period $t$ divided by operating profit of period $t-1$

b. Capital, consisting of:

- Capital Adequacy Ratio (CAR) is the ratio of Total Capital to Risk Weighted Assets (RWA) which is measured from June 2008 to December 2010;
- Composition of Capital: it is the ratio of Tier 1 (core capital) of the RWA which is measured from June 2008 to December 2010 .

\section{Analysis Technique}

Statistical analysis which was used to test the hypothesis is ${ }^{i i}$ Structural Equation Model(SEM) based on component/variant. This SEM was done with applied Generalized Structured Component Analysis (GSCA) method because it is considered to have ${ }^{\text {iii }}$ been able to predict in a model analysis (predictive model) and it is also useful for confirming the model based on the empirical data. (Ghozali, 2008: 4). In addition, GSCA method was done to assess hypothesis because it has ability to settle the analysis with small data (e.g., $\mathrm{n}<100)$ and also able analyze equation with formative and reflexive indicators.

The early stage of the analysis is by using GSCA that is to design structural model relationship between latent variables (Solimun, 2012: 22). This study focuses on performance management in implementing the bank corporate governance and risk mitigation, especially: liquidity risk, credit risk, market risk, and operational risk in order to achieve profitability and capital performance. The bank's business is inseparable from risk, where the risk must be identified and mitigated through good governance. The level risk of the bank determines the degree of bank corporate governance in order to achieve the expected performance. On the other hand the risk profile of banks can also affect the performance of the bank without mediation by GCG. Based on the factors mentioned above, the flow of diagram is as shown in Figure 1.

The next step is determination of the nature of each indicator of latent variables, what included reflexive or normative models. Reflexive indicators model assumes that variation is a function on the indicator plus an error; in reflexive models, latent variable illustrated with elliptical shape with a few arrow from latent variables to indicators. Normative indicator model is for the latten variables and these variables are formed from several indicators. Thus, this model has the characteristic of composite variable. The 


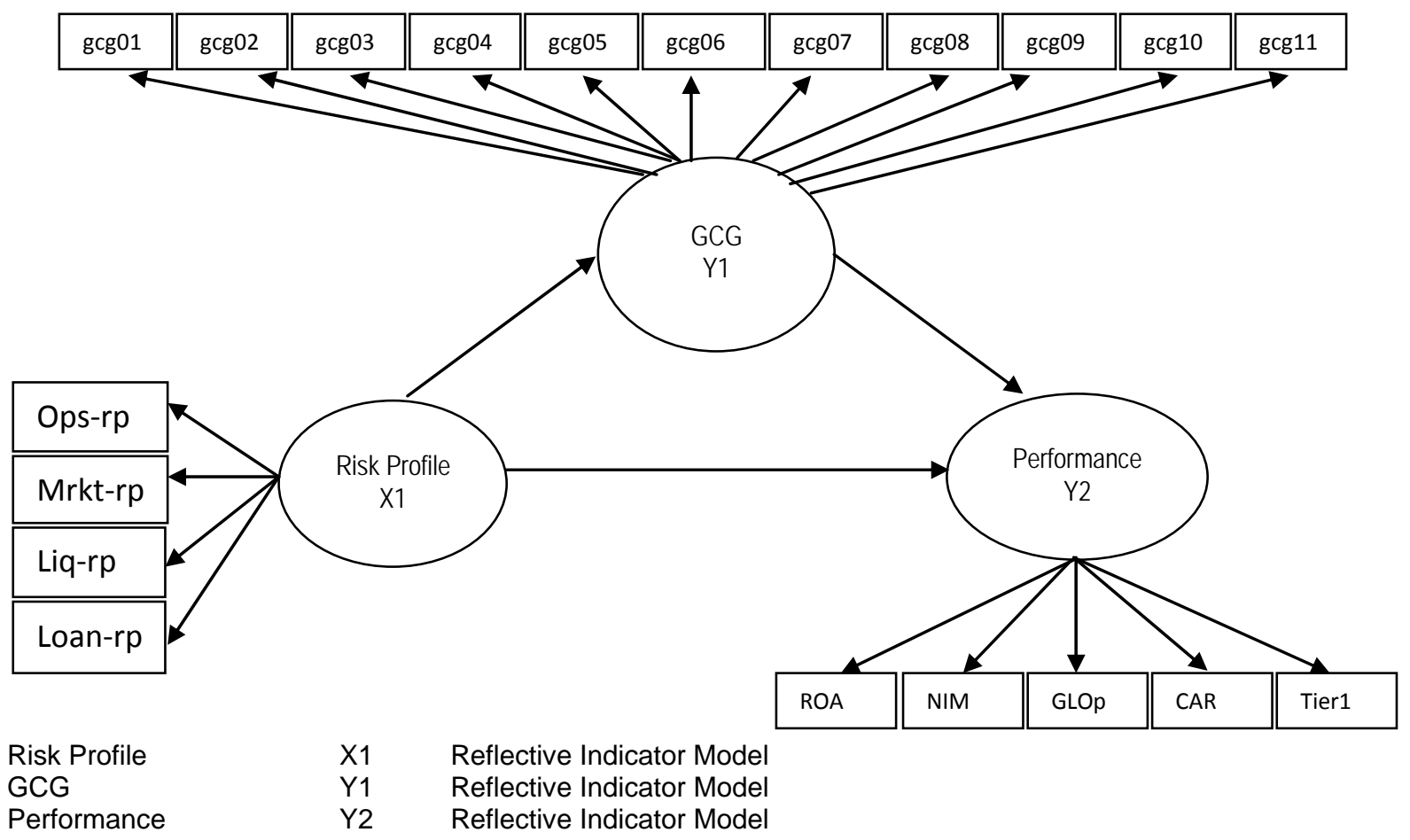

Figure 1. Research Model: GCG Mediation

normative models with its latent variables is illustrated in the form of ellipse with some arrows from the latent variable to indicator.

Based on the description, in this study the model indicators were categorized as reflexive variables namely:

1) Variable of Risk Profile (X1) is reflected by the four main types of risk: liquidity risk, credit risk, market risk and operational risk

2) Variable of banking corporate governance indicators (Y1) reflected by eleven types of assessment in accordance with Bank Indonesia Regulation No.8/4/PBI/2006

3) Variable of commercial banks performance (Y2) is reflected by the performance profitability (ROA, NIM, Operating Profit Growth), and performance of capital (CAR, Tier-1 ratio).

The construction of the path diagram can be seen in Figure 1.

\section{Structural Model}

Structural model is a specification of the relationship between latent variables that describe the relationship between these latent variables. It is assumed that the latent variables and indicators when they are standardized they are so constant $=0$ and they can be omitted from the model.

The influence of the risk profile (X1) to GCG (Y1):

$$
\mathrm{Y}_{1}=\beta_{11} \cdot \mathrm{X}_{1}+\varepsilon_{1}
$$

The influence of the risk profile $\left(\mathrm{X}_{1}\right)$ to Bank Performance $\left(\mathrm{Y}_{2}\right)$ :

$$
\mathrm{Y}_{2}=\beta_{21} \cdot \mathrm{X}_{1}+\varepsilon_{2}
$$

The influence of GCG $\left(\mathrm{Y}_{1}\right)$ to Bank Performance $\left(\mathrm{Y}_{2}\right)$ :

$$
\mathrm{Y}_{2}=\beta_{31} \cdot \mathrm{Y}_{1}+\varepsilon_{3}
$$

\section{Parameter Estimation}

The measurement of estimation method on GSCA is the least squares method. The measurement and structural models are combined into the model so that the calculation of the estimated parameters can minimize residual oriented model which has been combined. When this process is finished, it is then used to minimize residual 
of integrated models Alternating Least Square ALS.

\section{Measures of Fit Measurement Model}

a) Convergent Validity

This illustrates the validity of the size of the correlation between the sore reflective indicators with latent variables; if $p<0.05$, the indicator is valid to describe the latent variables.

b) Discriminant Validity

The validity reflective indicator is based on the value of Average Variance Extracted (AVE) in which this can compare the value of the square root of AVE of each latent variable with the correlation between another variables in the model. If the squared root of AVE latent variable is greater than the latent variable correlation across the latent variable, it indicates that the model have good validity.

c) Internal Consistency Reliability

The group indicator measuring a variable has better as internal consistency reliability if it has alpha $\geq 0.5$

\section{Measures of Fit Structural Model}

Goodness of Fit of structural model is measured by the FIT; there are two sizes, namely: a) FIT: shows the total variance all variables that can be explained by structural model FIT value have ranges between 0 and 1 , the greater value of the FIT, the greater variable proportion can be explained by the model.

b) A FIT (Adjusted FIT): can be used to compare model. The model with largest A FIT denote better model.

\section{The Research Result}

\section{Risk Profile, GCG, Earning and Capital Analysis}

Risk profile of the banks show that during the study period, on average decline in liquidity risk and operational risk, while the market risk and credit risk, there is a slight increase. When attributed with the implementation of GCG in these banks during the period of the study, it showed that the composite score (after being in reciprocal) becoming better (increase). The result showed that during the period GCG implementation, the risk can not entirely be mitigated. Although the GCG implementation is much more conducted, it cannot yet fully decrease credit risk and market risk. This is because of the risk which is greatly influenced by external conditions. On the contrary, the liquidity risk and operational risk are determined by the bank's internal policies. The position of risk profile during the study period can be seen in Figure 2.

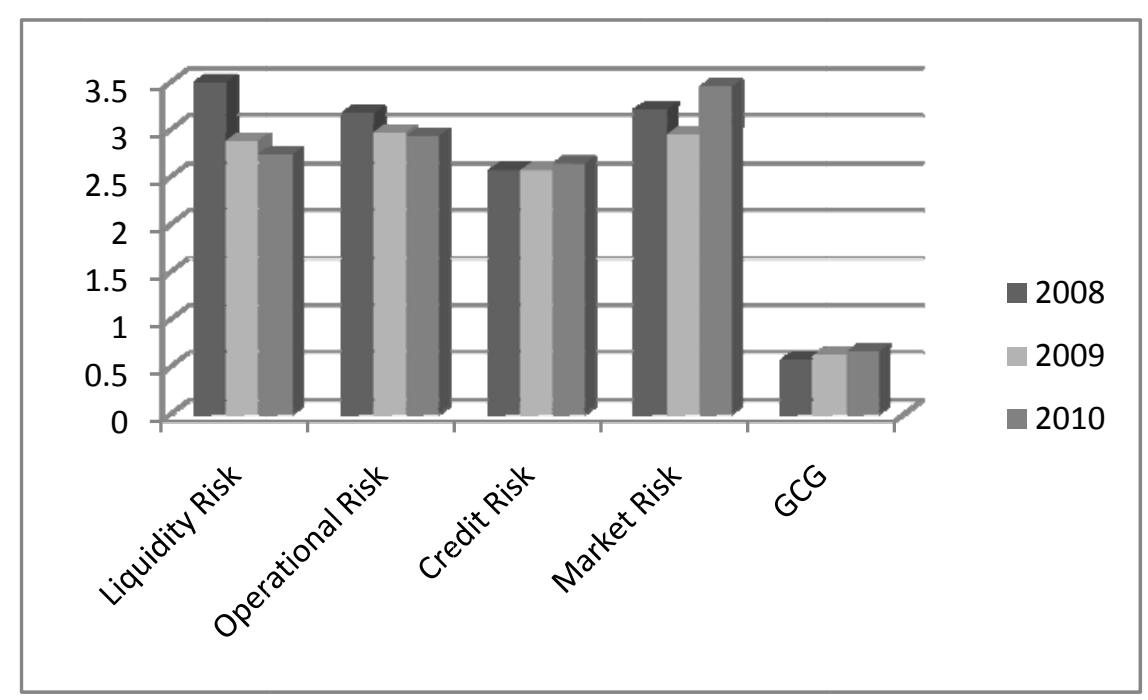

Figure 2. Risk Profile Position 2008-2010 


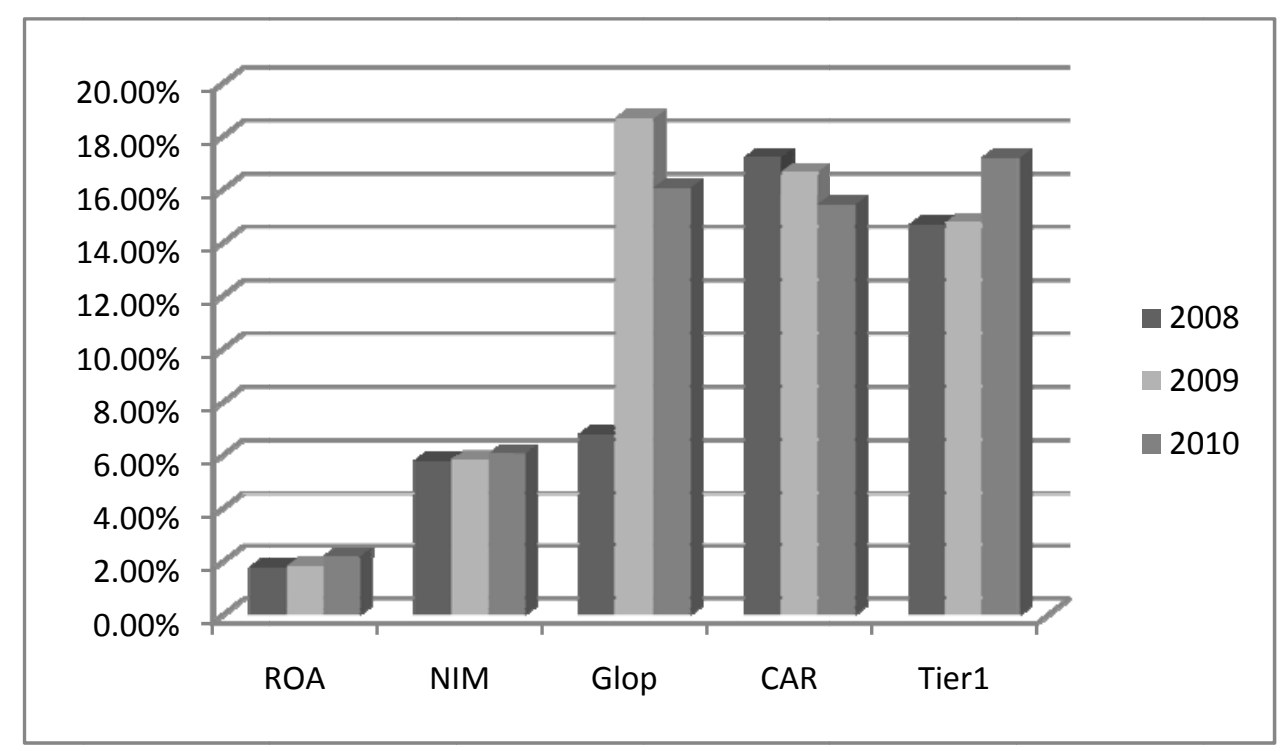

Figure 3. Position of Earning Performance and Capital

The increase of GCG composite rank during the observation was followed by the increase of earnings performance. However, there is a decrease in capital performance. This is probably due to increased credit risk and market risk, thereby increasing the risk-weighted assets, as presented the Figure 3.

\section{Measures of Fit Model Analysis}

As described in the analytical technique, the measurement is based on the estimates of loading and significance. This is due to the fact that all variables in the measurement model are reflexive.

\section{Risk Profile Variables}

Four indicators in risk profile are measured for describing the risk profile variables which do not have significant loading estimate $(\mathrm{CR}<1,96$ or $\mathrm{p}>0,05)$. So, it can be interpreted that four variables have convergent validities. These are considered unfavorable to describe the risk profile. In addition, the AVE value for risk profile variable is 0.644 and the squared root of the AVE is 0,803 . This value is greater than the value of correlation risk profile against other latent variable (Table 2). Therefore, it can be interpreted that the four indicators on the risk profile variables have good discriminate validity. Of the four indicators, liquidity risk indicator variable is more able to describe the risk profile because it has loading estimate value that is equal to 0.689 , greater than other three indicators loading estimate. The results of this study indicate that banks prefer liquidity management in assessing the risk profile.

Table 2. Model Measurement of Risk Profile Variable

\begin{tabular}{lccc}
\hline \multirow{2}{*}{ Indicator } & \multicolumn{3}{c}{ LOADING } \\
\cline { 2 - 4 } & Estimate & $\mathrm{SE}$ & $\mathrm{CR}$ \\
\hline Liquidity Risk & 0.689 & 0.671 & 1.03 \\
Credit Risk & -0.561 & 0.582 & 0.96 \\
Market Risk & 0.344 & 0.438 & 0.78 \\
Operational Risk & 0.684 & 0.664 & 1.03 \\
\hline \multicolumn{4}{c}{$\mathrm{AVE}=0.644, \mathrm{Alpha}=0.507$} \\
\hline Source: GSCA Output
\end{tabular}

\section{GCG Variable}

GCG variable is an indicator variable with a model that is reflexive, so the measurements for Measures of Fit based on its loading value is to look at the significance of loading, for example when it is significant (e.g., CR $>1,96$ or $\mathrm{p}<$ $0.05)$, it means that the measurement model is valid. There are eleven indicators that can describe the corporate governance variables, and all indicators have significant loading estimate, so that it can be interpreted that the 11 indicators have good convergent validity for describing the variable of GCG. 
The AVE value GCG variable is 0.528 , so that the square root of the AVE is 0.727 , this value is greater than the value of the variable GCG correlation with other latent variables (see Table 3). From the evidence in that table, it can be interpreted that 11 indicators of GCG variables also have good validity discrimination. Of the eleven indicators, transparency of financial and non-financial indicators are better able to describe the corporate governance variables because it has a larger loading estimate that is equal to 0.807 when compared to ten other indicators loading estimate. This result gives the sense that the banks need to pay attention to transparency in implementing good governance.

\section{Bank Performance Variable}

The variable of bank performance is an indicator that is reflexive. Therefore, the measurements for measuring the models based on its loading value. This is done by looking at the significance of loading. For example, when it is significant (e.g., $\mathrm{CR}>1,96$ or $\mathrm{p}<0.05$ ), it means that the model measurement is valid. There are 5 indicators that can describe the variable of the bank's performance. In this case, there are three indicators that have significantly the loading estimate namely: ROA, NIM and CAR, so that it can be interpreted that the three of these indicators has good convergent validity for the variables describing the bank's performance.AVE value for the variable performance of banks is 0.651 so the square root of the AVE is 0.807 and this value is greater than the value of the variable correlation with the performance of banks other latent variables (Table 4). Thus it can be interpreted that the fifth variable performance indicators in this bank has a good validity discriminate.

Table $4^{\text {iv }}$ Model Measurement of Bank Performance Variables

\begin{tabular}{lccc}
\hline \multirow{2}{*}{\multicolumn{1}{c}{ Indicator }} & \multicolumn{3}{c}{ LOADING } \\
\cline { 2 - 4 } & Estimate & SE & CR \\
\hline Return On Asset & 0.795 & 0.204 & $3.89^{*}$ \\
Net Interest Margin & 0.748 & 0.143 & $5.21^{*}$ \\
Operating Profit Growth & -0.319 & 0.266 & 1.2 \\
Capital Adequacy Ratio & 0.547 & 0.230 & $2.37^{*}$ \\
Tier-1 Capital & 0.400 & 0.297 & 1.34 \\
\hline & \multicolumn{4}{c}{ AVE $=0.651}$, \\
& \multicolumn{4}{c}{ Alpha $=0.648$} \\
\hline
\end{tabular}

Source: GSCA Output

Among 5 variables, ROA can describe more about the bank's performance of because it has the biggest loading estimate that is 0.795 . This result gives the sense that the banks need to pay attention to the performance of profitability, ROA indicator in particular, in order to get a good performance appraisal.

Table 3. Model Measurement of GCG Variables

\begin{tabular}{lccc}
\hline \multicolumn{1}{c}{ Indicator } & \multicolumn{3}{c}{ LOADING } \\
\cline { 2 - 4 } & Estimate & SE & CR \\
\hline Implementation of tasks and responsibilities of the board of commissioners & 0.546 & 0.157 & $3.48^{*}$ \\
Implementation of tasks and responsibilities of directors & 0.725 & 0.080 & $9.11^{*}$ \\
Completeness and implementation committee assignments & 0.758 & 0.050 & $15.32^{*}$ \\
Handling conflicts of interest & 0.762 & 0.051 & $14.9^{*}$ \\
Implementation of compliance of banks & 0.800 & 0.080 & $10.02^{*}$ \\
The Implementation of the internal audit function & 0.596 & 0.126 & $4.71^{*}$ \\
The application of external audit function & 0.685 & 0.141 & $4.86^{*}$ \\
The function of risk management \& control system & 0.798 & 0.068 & $11.76^{*}$ \\
Provision of fund to related parties & 0.802 & 0.048 & $16.62^{*}$ \\
Transparency of financial and non-financial condition & 0.807 & 0.066 & $12.25^{*}$ \\
The bank's strategic plan & 0.657 & 0.061 & $10.74^{*}$ \\
\hline & \multicolumn{3}{c}{ AVE $=0.528$} \\
& Alpha $=0.908$ \\
\hline
\end{tabular}

Sources: GSCA Output 


\section{Analysis of measures of fit of structural models}

Table 5 shows summary of the results of Fit Measures of the structural models of this study where there are two sizes to perform the analysis namely the size of the FIT and AFIT.

Table 5. Measures of Fit Structural Model

\begin{tabular}{cc}
\hline \multicolumn{2}{c}{ Model Fit } \\
\hline FIT & 0.397 \\
AFIT & 0.375 \\
\hline Sources: GSCA Output
\end{tabular}

As presented in Table 5, the value of FIT from the structural model is 0.397 , which means that the model can explain all variants which formed a total of latent variables of 0.397 . It can also mean that the variability of the latent variables, namely risk profile, corporate governance, and bank performance can be explained by the model with the value of 39.7 per cent while the remaining 60.3 per cent is explained by other variables. Thus, with the value of 39.7 per cent can also mean that the model is not good enough to explain the phenomenon under study. AFIT value indicates the value of the FIT after adjustment, this is done considering the variables that affect the performance of the bank is not just one variable, but can be more than one variable. In terms of value AFIT the total variance of the latent variable: risk profile, corporate governance and bank performance can be explained by the model was 37.5 per cent, while the remaining 62.5 per cent is explained by other variables. Describes the ability of 37.5 per cent could mean that the model is not good enough to explain the phenomenon under study. There are other factors that can affect bank performance which may not be included in this research model such as economic condition and banking regulation. Qualitatively, these factors can be included into operational risk measurement while operational risk in this reasearch was measured only by BOPO ratio. Other factors that can affect the bank performance is the management speed of anticipating the identified potential risk. Some large banks immediately carry risk mitigation sothat their performance could be saved. Of course, these qualitative factors still potential and therefore, for further research it is important to pay attention to such factors so that the FIT and AFIT values are not too high.

\section{Hypothesis Testing}

\section{First Testing Hypothesis Results}

The evidences as in Table 6 show that the estimated value of the parameter influences the bank's performance as in bank's risk profile is 0.077 with a standard error of 0.206 so that obtained Critical Ratio (CR) of 0.37. The CR value is not significant at the 95 per cent confidence degree, so that it can be stated that the risk profile has no significant positive effect on the performance of the bank. It can be concluded that the first hypothesis $\left(\mathrm{H}_{1}\right)$ of this study was rejected.

The positive value which is estimated shows that the higher risk profile will contribute to higher revenue and will further increase profits. The increased profits will increase bank capital, particularly in core capital. Increased earnings and capital will also mean increased bank performance. The influence the risk profile of the bank's performance is not significant due to the risk measurement methods. Where the risk measurement used in this study utilizing historical data from published financial statements while measuring risk should be directed to the future

Table 6. Structural Model of Path Coefficients

\begin{tabular}{lcccl}
\hline \multicolumn{1}{c}{ The Line of Structural Model } & Estimate & SE & CR & Significance \\
\hline Risk Profile $\rightarrow$ Performance & 0.077 & 0.206 & 0.37 & Not Significant \\
Risk Profile $\rightarrow$ GCG & 0.037 & 0.207 & 0.18 & Not Significant \\
GCG $\rightarrow$ Performance & 0.438 & 0.152 & $2.88^{*}$ & Significant \\
\hline
\end{tabular}

Sources: GSCA Output 
condition for the achievement of the performance bank guarantee. The results of this study do not support the results of previous studies, that the risk profile has no significant effect on the performance of banks. It is due to the fact that the previous studies did not use four financial ratios as an indicator to describe the profile of risk, but only they use one indicator, namely credit risk (Paudel: 2012).

\section{Results of the Second Hypothesis Testing}

Estimated value of the parameter influence the risk profile of the GCG is 0.037 with a standard error of 0.207 thus obtained Critical Ratio (CR) of 0.18 (Table 6). The CR value is not significant at the $95 \%$ confidence level, so that it can be stated that the risk profile has a positive effect that is not significant to the GCG. It can be concluded that the second hypothesis $\left(\mathrm{H}_{2}\right)$ of this study was rejected.

The estimated value is positive, indicating that the high-risk profile would require an increase in the management of bank governance by the management and officers of commercial banks. Influence on the risk profile of corporate governance is not significant, this may be caused due to the risk profile in this study was limited to just four types of risk. Therefore, it should add another ratio used to measure the four risk profiles, in addition to the need for a complete assessment of risk profiles by adding the four types of risk, namely, legal risk, reputation risk, strategic risk and compliance risk. Limitation indicator for the risk profile causes the inaccuracies in the measurement. Whereas measurement of GCG used in the study is complete indicator in accordance with Bank Indonesia regulations; where the measurement of GCG with eleven indicators show that implementation of risk mitigation has taken into account all types of commercial bank risk. Previous studies referenced do not test and analyze the effect of the risk profile on GCG implementation, so it is not comparable.

\section{Results of Third Hypothesis Testing}

As presented in Table 6, it shows that the value of the parameter estimation GCG influ- ence on the performance of banks is 0.438 with a standard error of 0.152 , thus earned Critical Ratio (CR) of 2.88. CR values are significant at the $95 \%$ confidence level, so it can be stated that GCG has a significant positive effect on the performance of the bank. It can be concluded that the third hypothesis $(\mathrm{H} 3)$ of the study received. Value estimates are positive, indicating that a good implementation of GCG will contribute on the increase in bank performance. GCG influence on the performance of a significant bank can be interpreted that a good governance implementation can lead the organization on one goal. Transparency of financial and non-financial is a key indicator on assessment of GCG (Table 3), thus transparency is a factor that will make the whole organization to move in the same direction, namely the achievement of the strategic plan of the bank.

The results of this study support the results Trinanda and Didien (2012) research where GCG has significant influence on the performance of profitability as measured by ROA, ROE, ROI and NPM. Its also supports the results of research Sam 'Ami (2008) where GCG significant positive effect on the bank's performance, and the results Peong and Devinaga research (2010) shows that corporate governance has a significant positive effect on bank performance and Cristoper (2009) found that the implementation of GCG has an important influence on the performance of the banks.

\section{Results of the Fourth Hypothesis Testing}

Based on testing of three hypotheses previously, there was only one accepted hypothesis that states there is an effect of the implementation of corporate governance on the performance of the bank. Due to the insignificant for the first and second hypotheses, it also leads to the hypothesis 4 to be rejected. This is also due to the mediating variables in which it requires that the relationship between latent variables in the structural model should have a significant effect. In other words, the mediating variable requires that the relationship between latent variables in the structural model should have a significant effect. Rejection the fourth hypothesis indicates 
that the GCG variable cannot be used as variable that mediates the effects of the bank's risk profile on the performance. The failure as a mediating variable can be caused by the failure of the risk profile variables as explanatory variables for the implementation of good corporate governance and bank performance variable.

\section{CONCLUSION}

Based on the description and results of hypothesis testing, it can be concluded as the following:

1. The results show that during the study period, the risk profile has no significant and positive effect on the performance of the bank. In fact, these four indicators (liquidity risk, credit risk, operational risk and market risk) have a loading estimate that is not significant. For that reason, it could be interpreted that this indicator has four convergent validities which are unfavorable for the risk profile for describing variable. However, the positive sign of the estimated value suggests that a high risk profile can contribute to the high performance of the bank. Of the four indicators, liquidity risk indicator is the indicator variable that could describe the risk profile, for loading estimate value which is greater than three other indicators that is equal to 0.689 . This result provides the sense that the bank is more concerned with liquidity risk in assessing the risk profile.

2. Risk profile has no significant and positive effect on corporate governance. The positive sign on the estimated value suggests that a high risk profile will require improved management of bank governance by the management and officers of commercial banks. This study is limited to just four types of risk. Therefore, it still needs more complete assessment for the risk profile. For example, the restriction indicator for the risk profile leads to inaccuracies in the measurement of GCG given measurement using a complete indicator with eleven indicators. As such, the measurement of GCG for risk mitigation has to consider all kinds of risk for commercial banks.
3. The implementation of GCG has a significant and positive effect on the performance of the go-public commercial banks, with Critical Ratio (CR) of 2.88. Positive sign on the estimated value indicates that the implementation of good corporate governance contributes to the improved performance of the bank. From eleven indicators used to measure corporate governance, transparency of financial indicators and non-financial are the key indicators in the assessment of GCG, with the estimated value of 0,807 .

4. GCG variable cannot be inferred as a variable that is able to mediate the effect of the risk profile of the performance of go-public commercial banks.

5. The first and second hypotheses are not significantly proved because the fourth hypothesis is rejected. This is due to the fact that the mediating variable is required that the relationship between latent variables in the structural model should have a significant effect.

The results of this study has several limitations, that is weakness in the measurement of the risk profile that is only using four types of risk and do not use other types of risk, namely legal risk, reputation risk, strategic risk and compliance risk. Another problem is the risk profile measurement method which is based on published financial statement data using only one ratio of several ratios that should be measured. Each measurement is an indicator of the risk of historical data, while the measurement of the risk profile should also be based on the possibility of potential losses in the future.

This study result recommends that:

1. The go-public commercial banks should maintain their liquidity risk in order to keep getting the trust of the public. They should also consider liquidity risk which is an indicator variable that can describe the risk profile the most. The banks as intermediary institutions must always maintain their liquidity to meet withdrawals by depositors and borrowers. 
2. The go-public commercial banks should be able to improve their quality of all components of the assessment of implementation of GCG. Particularly, they have improve transparency of financial and non-financial. This is due to the importance of implementing GCG which has a significant and positive effect on the performance of go-public commercial banks.

3. There are three indicators of the performance of banks that have significant loading estimate namely ROA, NIM and CAR so that it can be interpreted that all these indicators have good convergent validity for describing variable bank performance. Banks are expected to continue to maintain their profitability, because it will improve their performance.

4. For further studies, it is important for the researcher to consider the types of indicators and methods of measurement for the risk profiles more considerably so that it can see the future potential events (looking forward) and not only pay attention to the measures that have historically occurred.

5. Based on the test results, it supports the application based bank rating of RBBR as determined by Bank Indonesia that has enforced the program since in 2012.

\section{REFERENCES}

Astrid Van Landschoot, Rudi Vander Vennet, 2002.

"How Does a Banks' Risk Profile Influence the Effect of Credit Risk? Evidence from Bank Stock Market Return". Social Science Research Network., http://papers.ssrn.com.

Bank Indonesia, 2006."Peraturan Bank Indonesia Nomor 8/4/PBI/2006, tentang Pelaksanaan Good Corporate Governance Bagi Bank Umum" (PBI No.8/4/PBI/2006, about: Good Corporate Governance Implementation). Jakarta:Bank Indonesia.

Bank Indonesia, 2009."Peraturan Bank Indonesia Nomor 11/25/PBI/2009, tentang Perubahan atas Peraturan Bank Indonesia Nomor 5/8/PBI/2003 tentang Penerapan Manajemen Risiko bagi Bank Umum" (PBINomor 11/25/PBI/2009, about:
Indonesian Banking Regulation Amendment No. 5/8/PBI/2003 regarding Risk Management for Banks). Jakarta: Bank Indonesia.

Bank Indonesia, 2011.Surat Edaran Bank Indonesia Nomor 13/24/DPNP. "Penilaian Tingkat Kesehatan Bank Umum (SEBI No. 13/24/DPNP "Assessment of Commercial Banks Soundness)". Jakarta: Bank Indonesia..

Bank Indosesia,2011.Surat Edaran Bank Indonesia Nomor 13/30/DPNP tanggal 16 Desember 2011. "Perubahan Ketiga atas Surat Edaran Bank Indonesia Nomor 3/30/DPNP tanggal 14 Desember 2001 perihal Laporan Keuangan Publikasi Triwulanan dan Bulanan serta Laporan Tertentu yang Disampaikan kepada Bank Indonesia (Third Amendment SEBI No. 3/30/DPNP December 14, 2001, concerning the Quarterly and Monthly Financial Statements and Certain Report Submitted to Bank Indonesia) "Jakarta: Bank Indonesia.

Basel Committee on Banking Supervision, 2004. "International Convergence of Capital Measurement and Capital Standards". Bank For International Settlement, Press \& Communication, CH-4002 Basel, Switzerland

Cristoper, Mo Fung Yung, 2009.“The Relationship between Corporate Governance dan Bank Performance in Hongkong".Disertation, http: //aut.researchgateway.ac.nz/ handle/10292

Ghozali, Imam. 2008. "Generalized Structured Component Analysis (GSCA)". Model Persamaan Struktural Berbasis Komponen (Structural Equation Model-Based Components). Semarang: Diponegoro University.

Hempel,G. H., Simonson,1999, Bank Management Text and Cases. $5^{\text {th }}$ Edition. New York: John Wiley \& Sons Inc.

Nurhidayah, Budi Artinah, 2012. "Pengaruh Risiko Keuangan terhadap Earning Response Coefficient (ERC) pada Perusahaan Perbankan di Bursa Efek Indonesia (The influence of Financial Risk to Earnings Response Coefficient (ERC) on Banking companies in Indonesia Stock Exchange)" Journal of Social Sciences, $4,(1), 147-154$. 
Peong Kwee Kim, Devinaga Rasiah, 2010, “ Relationship between Corporate Governance and Bank Performance In Malaysia During the Pre and Post Asian Financial Crisis" European Jounal of Economic, Finance and Administration Science. ISSN 1450-2275 Issue 21, 2010, page $39-58$.

Ravi Prakash Sharma Poudel, 2012.”The Impact of Credit Risk Management on Financial Performance of Commercial Banks In Nepal”. International Journal of Art and Commerce, Vol 1 No.5, page 9-15.

Sam'Ami, 2008. "Pengaruh Good Corporate Governance dan Leverage terhadap Kinerja Keuangan pada Perbankan yang terdaftar di BEI TH 20042007(The influence of Good Corporate Governance and Financial Leverage on the Banks listed on the Stock Exchange TH 2004-2007)". Thesis, http:// eprints.undip.ac.id/1865

Sekaran, U. 2006. Research Methods for Business : A Skill - Building Approach, John Wiley \& Sons Inc, New York.
Solimun. 2012. Pemodelan Struktural : Generalized Structured Component Analysis GSCA (Structural Modeling: Generalized Structured Component Analysis GSCA). Malang: Statistics Program Studies, Mathematics Department UB.

Trinanda, Didin Mukodin, 2012."Pengaruh Penerapan GCG terhadap Kinerja Keuangan pada Perusahaan SektorPerbankan (The Influence of GCG implementation of the Company's Financial Performance in the Banking Sector)" EJournal Ekonomi, http://hdl.handle.net/ $123456789 / 1434$

Yustriati Nur Farida, Yuli Prasetyo, Eliada Herwiyanti, 2012. "Pengaruh Penerapan Good Corporate Gocernance terhadap Timbulnya Earning Management dalam Menilai Kinerja Keuangan pada Perusahaan Perbankan di Indonesia (The influence of Implementation of Good Corporate Governance to the emergence of Earning Management in Assessing Financial Performance on the Banking Companies in Indonesia)". Journal of Business Economics and Accounting, 12 (2), 69-80.

\footnotetext{
${ }^{\mathrm{i}}$ Try to highlight the main division of this work to be different from the subdivisions

${ }^{\mathrm{ii}}$ Grammatically incorrect (do not use direct translation)

${ }^{\mathrm{iii}}$ Grammatically incorrect

${ }^{\mathrm{iV}}$ It might be better to supply additional description
} 